\title{
Katselun tuolla puolen - tv-ohjelmien vastaanottotutkimuksen uusia tuulia
}

Televisio-ohjelmien empiirisen vastaanottotutkimuksen historia on lyhyt. Seuraavassa katsauksessa tarkastelen joitakin — henkilökohtaisten kiinnostuksen pohjalta valittuja - tuoreita tutkimuksia viime vuosikymmenellä tehtyä tutkimusta vasten ja yritän erottaa, millaisia uusia kysymyksiä ja asetelmia ne tuovat esiin. (80-luvun tutkimuksesta ks. esim. Alasuutari ja Kytömäki 1991; Montonen 1991, 8-29)

Televisio-ohjelmien empiirisen vastaanottotutkimuksen "uuden aallon" synty on tapana ajoittaa David Morleyn vuonna 1980 ilmestyneeseen Nationwide-tutkimukseen. 80-iuvun puolimaissa empiirinen vastaanottotutkimus alkoi jo erottua omana alueenaan esimerkiksi Lontoon kansainvälisissä televisiotutkimuskonferensseissa. Käsin kosketeltavien yleisön edustajien televisiokokemuksia ja -tulkintoja tarkastelevan tutkimuksen kenttä oli hajanainen mutta rajallinen. 90-luvun alkuun mennessä lähestymistapa on saanut pitävän jalansijan ainakin eurooppalaisessa viestintätutkimuksessa. Konkreettisten katsojien televisiotulkinnat eivät ole jääneet vain viestintätutkimuksen kiinnostuksen kohteeksi - aihetta tarkastellaan tai sivutaan myös muiden yhteiskuntatai humanististen tieteiden piirissä. Tutkimuksia on tehty kymmeniä, ehkäpä jo satoja, jos eri tasoiset opinnäytetyöt otetaan huomioon.

Tutkimusjoukko on hyvin heterogeeninen. Peter Dahlgren (1987) on luonnehtinut tv-ohjelmien vastaanottoa koskevaa tutkimusta tähtäämiseksi liikkuvaan maaliin. Ainnastus näyttää sopivan myös itse tutkimusalueen tarkasteluun. Juuri kun kuvittelee saaneensa kokonaiskuvan siitä, mitä ja millä keinoin tutkimuksissa tarkastellaan, jostain pulpahtaa kiinnosiava artikkeli, joka avaa uria uudenlaisille näkökulmille.

Yksituumaisuutta ei näytä vallitsevan siitä, mitä tv-ohjelmien empiirinen vastaanottotutkimus oikeastaan on tai mitä sen pitäisi olla. Klaus Bruhn Jensen ja Karl Erik Rosengren (1989) ovat yrittäneet tiivistää sen, mikä erilaisten tutkimusperinteiden pohjalta tehdyille konkreettisten vastaanottajien tulkintoja koskeville tutkimuksille on ollut yhteistä. Heidän mukaansa vastaanottotutkimus on yleisnimitys, joka kattaa erilaisia yleisötutkimuksen muotoja. Yhteistä on se, että vastaanottoa tarkastellaan tavalla, joka pyrkii yhdistämäën sosiaalitieteellisiä ja humanistisia näkökulmia. Kohteena on sekä joukkoviestinnän sisältö että yieisö. Tutkimus on empiiristä ja kvalitatiivista. Välittömänä tavoitteena on selvittää vastaanottoprosessin luonnetta. Koko joukkoviestintäprosessissa vastaanotto nähdään solmukohtana, jolla on merkitystä sekä viestinnän käytön että vaikutusten kannalta.

Valitsemani tutkimukset mahtunevat Jensenin ja Rosengrenin määritelmän puit- 
teisiin — ne edustavat erilaisia vastaanottajapainotteisia televisiotutkimuksen lähestymistapoja.

\section{Ylikansallisesta kansalliseen}

Ehkä selvin muutos näyttää olevan tapahtumassa kulttuuriseen vertailuun keskittyvien tutkimusten kysymyksenasetteluissa. 80-luvun kuluessa tehtiin koko joukko tutkimuksia, joissa tarkasteltiin Dallasin tai Dynastian, ylikansallisten amerikkalaisvalmisteisten menekkiohjelmien vastaanottoa kulttuuritaustaltaan ei-amerikkalaisten vastaanottajien parissa. Tutkimusten pontimena oli kiinnostus siihen, miten Dallasin kaltaiset ohjelmat onnistuvat ylittämään kieli- ja kulttuurirajat sekä huoli ylikansallisen televisioviihteen kulttuurisista tai ideologisista vaikutuksista. 90-luvun alussa kysymyksenasettelut näyttävät muotoutuvan uudelleen. Ylikansallisten massakulttuurituotteiden sijasta tai niiden rinnalla tarkastellaan kansallista tuotantoa olevia ohjelmia ja niiden vastaanottoa.

Daniel Biltereyst (1991) on vertaillut amerikkalaisen ja flaamilaisen televisiosarjan vastaanottoa belgialaisten katsojien parissa. Biltereystin tutkimusta leimaa Tamar Liebesin ja Elihu Katzin Dallas-projektin (Liebes \& Katz 1990) lähtökohtien ja tulosten kritiikki. Liebesin ja Katzin mukaan Dallasin menestyksen salaisuus pillee toisaalta sarjan yleisinhimillisiin ongelmiin ankkuroituvissa aineksissa, toisaalta monitulkintaisuudessa, joka antaa vastaanottajille mahdollisuuden taivuttaa sisältöä omaan kulttuuriseen kontekstiinsa sopivaksi. Biltereystin mukaan tämänkaltaiset tulokset vähättelevät amerikkalaisten ohjelmien vaikutuksia ei-amerikkalaisiin yleisöihin ja ylikorostavat vastaanottajien vastustuskykyä. Suurin ongelma on hänen mukaansa tutkimusasetelmassa. Jotta empiirinen vastaanottotutkimus voisi kantaa hedelmää, vertailuasetelmien tulisi olla monipuolisia ja vertailuja tulisi tehdä eri tasoilla.

Anne Hjort (1985) tarkasteli jo 80-luvun puolimaissa rinnan Dallasin ja tanskalaisen Krigsdøtre-sarjan vastaanottoa ja havaitsi niiden tarjoavan naiskatsojille vallan erilaisia katselukokemuksia. Sarjat olivat luonteeltaankin erilaisia, joten tulokset eivät olleet järin yllättäviä. Krigsdøtre kuvasi naisten arkielämää sodanjälkeisessä Tanskassa ja sarjan tekijätkin olivat naisia.

Daniel Biltereyst on valinnut tutkimuksensa kohteeksi kaksi belgialaisyleisölle tuttua ja mahdollisimman samankaltaista tilannekomediaa. Amerikkalainen She's the Sheriff ja flaamilainen De Kollega's ovat hänen mukaansa saman lajityypin edustajia ja vertailukelpoisia tapahtumaympäristön, henkilöhahmojen, tarinoiden ja teemojen suhteen. Liebesin ja Katzin Dallas-projektiin kohdistamasta kritiikistään huolimatta Biltereyst on havainnut heidän käyttämänsä tutkimusmenetelmät toimiviksi — suorastaan parhaiksi useiden tutkimusprojektissa kokeilemiensa menetelmien joukosta. Ryhmäkeskusteluaineistoja hän on analysoinut Liebesin ja Katzin diskurssiluokituksia käyttäen. (Dallas-projektin menetelmistä ks. esim. Montonen 1990.) Kuten kaikkien Dallas-projektin ryhmien puhe, myös belgialaisten vastaanottajien puhe oli edestakaista liikettä eläytymisen ja etääntymisen välillä. Belgialaiskatsojien suhde flaamilaiseen sarjaan oli kuitenkin kaikilla tasoilla eläytyvämpi kuin heidän suhteensa amerikkalaiseen sarjaan. Biltereyst arvelee, että kun vastaanottajat eläytyivät vain heikosti amerikkalaiseen sarjaan, myös sen vaikutukset "mikrotasolla" ovat vähäisiä. 
Liebesin ja Katzin pohdinnat Dallasin mahdollisista ideologisista vaikutuksista pohjautuvat hypoteesiin, jonka mukaan referentiaalinen puhe, "tosissaan" puhuminen, reaalisen ja kollektiivisen viiteryhmän korostaminen ja normatiivisuus heijastavat eläytymistä. Kriittistä etääntymistä heijastavat vastaavasti metakielellinen puhe, "leikillinen" puhe, abstrakteihin sosiaalisiin ryhmiin viittaaminen ja lakoniset sisältötulkinnat. Metakielellisen puheen he ovat jakaneet "kuumaan" ja "viileään" tyyppiin. Viileä metakielellinen puhe heijastaa tietoisuutta ohjelmien luonteesta tiettyjä konventioita noudattavina tuotteina sekä tietoisuutta vastaanottajan omasta roolista tekstin tulkitsijana ja työstäjänä.

Liebes ja Katz (1990, 152-154) näyttävät olevan kahden vaiheilla sen suhteen, mitä merkitystä vastaanottotavan eläytyvyydellä/etääntyvyddellä ja kuumuudella/viileydellä on Dallasin kaltaisten ohjelmien ideologisten vaikutusten kannalta. Metakielellisyys ja leikillisyys saattaa heijastaa sitä, että vastaanottajilla on käytössään puolustusstrategioita ideologisia vaikutuksia vastaan. Toisaalta leikillisyys saattaa merkitä sitä, että vastaanottajat ovat alttiita uppoamaan liian syvälle mielikuvitusleikkiin. Ohjelman rakennetta tarkkaileva vastaanottaja ei ehkä kiinnitä riittävästi huomiota ideologisiin sanomiin. Vastustavia luentoja työstävä katsoja saattaa puolestaan joutua oman ideologiansa uhriksi. Kaikkien näiden varauksien jälkeen he kuitenkin arvelevat, että kaikkein alttiimpia ideologisille vaikutuksille ovat ne katsojat, jotka näkevät ohjelman kuvaaman maailman totena vaikka eivät sen menoa ja arvoja hyväksyisikään.

Biltereyst peräänkuuluttaa tekstissään Dallas-projektin keskeisten käsitteiden ja tulosten uudelleenarviointia. Eläytymiseen, etääntymiseen ja ideologisiin vaikutuksiin liittyvät kysymykset eivät kuitenkaan näytä vallan yksioikoisilta, joten viisastenkiven löytymistä saataneen vielä odotella.

Gerlinde Frey-Vorin (1991) tutkimus liittyy keskusteluun eurooppalaisten televisiokulttuurien mahdollisesta yhdentymisestä. Tutkimuksen kohteena on kaksi eurooppalaista saippuasarjaa, saksalainen Lindenstrasse ja englantilainen EastEnders, sekä kummankin tuotanto ja vastaanotto. Lindenstrasse ja EastEnders ovat Frey-Vorin mukaan saman lajityypin - "sosiaalirealistisen saippuaoopperan" — kansallisia variantteja, joilla on omat kerronnalliset ja ilmaisulliset erityispiirteensä. Havainnointiin ja haastatteluihin pohjautuvassa tuotantotutkimusosassa Frey-Vor jäljittää sitä, miten kansainvälinen lajityyppi adaptoituu erilaisiin kulttuurisiin ja yhteiskunnallisiin konteksteihin. Vastaanottotutkimusosassa hän tarkastelee sarjojen yleisöjä, sarjojen herättämiä reaktioita ja vastaanottajien käsityksiä sarjojen eroista ja yhtäläisyyksistä. Tutkimuksen tämä osa pohjautuu katsojatilastoihin, Saksassa ja Englannissa suoritettuihin kyselytutkimuksiin ja ryhmäkeskusteluaineistoihin. Samansisältöiset kyselyt suunnattiin kummassakin maassa televisioyleisöä edustavalle otokselle. Kysymykset koskivat muun muassa katselun motiiveja, sitä missä määrin sarjoissa kuvatut ongelmatilanteet muistuttivat tosielämän tilanteita, ja sitä missä määrin vastaajilla oli tapana keskustella sarjoista muiden kanssa. Ryhmäkeskusteluja varten kummastakin maasta oli etsitty pariskuntia, joille esitettiin yksi jakso Lindenstrassesta ja yksi EastEndersistä. Keskusteluaineistot osoittivat, että vastaanottajat tunnistivat sekä sarjoja yhdistävän lajityypin että joukon niitä erottavia tyylipiirteitä. 


\section{Keskiössä kulttuurinen identiteetti}

Tyystin eurooppalaisesta poikkeavaan yhteiskunnalliseen ja kultturikontekstiin sijoittuu Amita Malwade-Rangarajanin (1991) tutkimus intialaisen kehityspropaganda-saippuaoopperan vastaanotosta Delhissä. Kolmannen maailman maissa joukkoviestinnän rooli yhteiskunnallisen muutoksen ja kehityksen välikappaleina on Malwade-Rangarajanin mukaan ollut kahtalainen: yhtäällä joukkoviestintä on valjastettu luomaan kansallistunnetta, toisaalla sen avulla on pyritty sovittamaan yhteen ulkoinen yhtenäisyys ja sisäinen erilaisuus. Intian kansallinen televisio Doodarshan on pyrkinyt samanaikaisesti kumpaankin tavoitteeseen jakamalla ohjelmistonsa kansalliseen (esim. Mahabharatha) ja alueelliseen osaan. Malwade-Rangarajanin tutkimuksessa tarkastellaan Delhin alueella 80-luvun puolivälissä esitettyä, "Kansasta" kertovaa Hum Log- saippuaopperaa, jonka tavoitteena oli tarjota viihteen muodossa kansallista yhtenäisyyttä ja kulttuurista moniarvoisuutta tukevaa valistusta. Sarjassa käsiteltiin myös muita kehitykseen liittyviä teemoja kuten perhesuunnittelua, naisten asemaa, lukutaito- ja kielikysymyksiä. Hum Log oli ensimmäinen saippuasarja, joka luotiin edistämään hallituksen kansallisuuspoliittisia tavoitteita. Malwade-Rangarajanin mukaan sarjassa erottui kaksi strategiaa: intialaisuuden määrittely toisaalta länsimaisuuden vastakohdaksi ja toisaalta monien alueellisten identiteettien rinnakkaineloksi.

Sarjan vastaanottoa tutkittiin haastattelemalla erilaisia sosioekonomisia ja kieliryhmiä edustavia delhiläisperheitä. Tavoitteena oli selvittää, missä määrin vastaanottajat hyväksyivät sarjan keskeiset viestit, vastustivat niitä tai esittivät neuvottelevia tulkintoja. Tekstissään Malwade-Rangarajan kuvaa kahden perheen suhdetta sarjaan. Kumpikaan ryhmä ei ohjelman tavoin määritellyt intialaisuutta länsimaisuuden vastakohdaksi vaan näki intialaisuuden länsimaisten ja itämaisten piirteiden sekoituksena. Kumpikin ryhmä hyväksyi näkemyksen, jonka mukaan intialaisuus ja erilaiset alueelliset identiteetit ovat sovitettavissa yhteen. Malwade-Rangarajanin mukaan tämä näkemys pohjautui ensi sijassa vastaanottajien omiin kokemuksiin sosiaalisesta todellisuudesta. Kansallisen identiteetin muotoutumisen kannalta avainasemassa ovat hänen mukaansa vastaanottajat, eivät joukkoviestimet.

Kulttuurisen identiteetin teema on myös Alison Griffithsin (1991) tutkimuksen keskiössä. Hänen tutkimuksensa aiheena on walesinkielisen saippuaoopperan rooli walesilaisidentiteetin muotoutumisen kannalta. Tutkimuksessa tarkastellaan Channel 4:n esittämän "Laakson kansasta" kertovan Pobol Y Cwm -sarjan vastaanottoa kaksikielisten nuorten parissa. Suosittua sarjaa on esitetty jo vuosia. Griffithsin mukaan sarja on hiljattain "herännyt eloon" ja muotoutunut kulttuurisesti ja poliittisesti "tiedostavammaksi". Sarjassa kuvataan eri kulttuurien välisiä jännitteitä ja yhteentörmäyksiä. Paitsi walesilaisten ja Yhdistyneen kuningaskunnan muiden kansojen välillä jännitteitä on myös pohjois- ja etelämurretta puhuvien walesilaisten välillä. Sarjassa esiintyy kummankin murrealueen edustajia. Koulussa järjestettyjä ryhmäkeskusteluja varten Griffiths oli valinnut sarjasta jakson "Invaasio", jossa walesilaisten ja ei-walesilaisten väliset jännitteet kärjistyvät, kun laakson tiiviseen kyläyhteisöön muuttaa englantilaisperhe.

Griffithsin haastattelemat nuoret identifioituivat voimakkaasti sarjaan sekä sosiaalisesta että kulttuurisesta näkökulmasta. Sarjan todenmukaisuutta vastaanottajat arvioivat suhteessa omiin kokemuksiinsa elämästä samankaltaisessa pienessä maaseu- 
tuyhteisössä. Laakson kansan kanssa kilpailevaa toista walesinkielistä saippuasarjaa he puolestaan arvostelivat "angloamerikkalaisuudesta", kulttuuristen erityispiirteiden vesittämisestä. Vaikka Invaasio-jaksoon liittyvät tulkinnat ja reaktiot olivat erilaisia, vastaanottajat olivat yhtä mieltä siitä, että teema oli tärkeä, ja että ohjelma kykeni käsittelemään sosiaalista ongeimaa tavalla, joka edesauttoi kulttuurisen identiteetin ylläpitämistä.

\section{Konstruktiivisia toisintoja}

Sekä Liebesin ja Katzin Dallas-projektilla että Morleyn Nationwide-tutkimuksella näyttää olevan vankka asema kïnnekohtina ja esikuvina. Jane Roscoen (1991) lähtökohtana on ollut Nationwide-tutkimuksessa testattu käsitys hallitsevista viesteistä, jota hän on soveltanut saippuasarja-aineistoon. Myös saippuasarjat saattavat vahvistaa ja legitimoida vallitsevaa yhteiskunnallista järjestystä. Saippuasarjoissa sivutaan mitä moninaisimpia sosiaalisen elämän ongelmia. Se, millaisia pulmia saippuasarjoissa otetaan esiin, miten niitä käsitellään ja millaisia ratkaisuja niihin tarjotaan, rajaa sekä sitä, mitkä asiat määrittyaät "ongelmiksi" että sitä, miten ongeimista on järkeenkäypää puhua. Tutkimusta varten Roscoe on valinnut EastEnders- ja Brookside-sarjoista katkelmat, jotka kuvaavat "yksilön ja yhteiskunnan kohtaamista". Tekstissään hän käsittelee lähinnä EastEndersista valittua katkelmaa, jonka aiheena oli raiskauksen oikeuskäsittely.

Nationwide-tutkimuksen malli on ollut pohjana myös vastaanottajien valinnassa. Katkelmat esitettiin kaikkiaan kahdelletoista lontoolaiselle naiselle ja miehelle, jotka edustivat samaa ikäryhmää (20-35 -vuotiaita) mutta erilaisia sosioekonomisia ja poliittisia asemia. Vastaanottajat on jaettu yhteiskunnallisesti "hallitsevassa", "alistetussa" ja "radikaalissa" asemassa oleviin. "Hallitsevassa" asemassa oleviksi vastaanottajat on luokiteltu muun muassa sen pohjalta, että he toimivat työssään johtavassa asemassa, ja että heillä on aineellisia intressejä, joiden vuoksi vallitsevan yhteiskuntajärjestyksen ylläpitäminen on heille edullista. "Radikaalissa" asemassa oleviksi vastaanottajat on puolestaan luokiteltu muun muassa sen pohjalta, että he ovat poliittisesti aktiivisia vallankumouksellisessa marxilaisessa liikkeessä. Jaottelu tuntuu harvinaisen selkeältä, mutta askarruttamaan jää se, miten taustatiedot on vastaanottajista saatu.

Ohjelmakatkelmien katselun jälkeen vastaanottajia haastateltiin henkilökohtaisesti. Roscoe on soveltanut diskurssianalyysia sekä ohjelmatekstien että haastattelupuheen analyysiin. Kummassakin analyysissa tuli esiin kaksi keskeistä teemaa: toisaalta aiheena olleiden ongelmien yksilöllisyys/yhteiskunnallisuus, toisaalta "järjestelmän" kyky selvittää ongelmatilanteita. Hallitsevassa asemassa olevien vastaanottajien tulkinnat noudattelivat teksteissä tarjottuja näkökulmia. Ohjelmien ongelmista puhuttiin yksilöllisinä ja niihin tarjottiin välittömiä ja lyhytaikaisia ratkaisuja. Muut vastaanottajat pohdiskelivat sitä, miten ohjelmien ongelmat liittyivät yhteiskunnalliseen eriarvoisuuteen, ja miten "järjestelmä" toimii valtaa pitävien ehdoilla. Etenkin "radikaalien" vastaanottajien radikaaleissa kannanotoissa heijastui Roscoen mukaan se, että vastaanottajat ottivat ohjelmakatkelmista puhuessaan käyttöön poliittiseen toimintaansa liittyvän aiemman pohdiskelun myötã muotoutuneita käsityksiä.

Nationwide-tutkimuksen "konstruktiivinen replikaatio" on tekeillä myös Ruotsissa. 
Birgitta Höijerin, Kjell Nowakin ja Sven Rossin (Höijer ym. 1991) REKK-projektissa vertaillaan erilaisten yleisöryhmien (naisten/miesten, työntekijöiden/toimihenkilöiden) fiktio- ja faktaohjelmien vastaanottotapoja. Ohjelma-aineisto koostuu Falcon Crestistä ja Tre Kärlekar -sarjasta valituista jaksoista sekä neljästä Rapport- ja Aktuellt-lähetyksistä valitusta uutisesta. Ohjelmat esitettiin Ruotsin radion tiloissa eri-ikäisille tukholmalaisille, joita haastateltiin henkilökohtaisesti sekä ohjelmien katselun jälkeen että myöhemmin kotona.

Tutkimusprojekti jakautuu kahteen itsenäiseen mutta samaa empiiristä aineistoa käyttävään osaan. Kjell Nowakin ja Sven Rossin tutkimusalueena on vastaanoton makrotaso. He keskittyvät niin sanomia kuin vastaanottajiakin konstituoivan sosiokulttuurisen järjestelmän suhteisiin. Ohjelmatarjontaa he tarkastelevat yhteiskunnan ideologisia ja kulttuurisia valtasuhteita uusintavana symboliympäristönä. Kysymyksenasettelu keskittyy sosiaaliseen stratifikaatioon liittyviin käsityksiin, jotka ovat keskeinen osa hallitsevaa ideologiaa. Sikäli kuin vastaanottajien käsitykset sosiaalisesta eriarvoisuudesta ja yhteiskuntaluokkien erilaisista elinehdoista aktivoituvat vastaanottoprosessissa, niiden oletetaan tulevan esiin henkilöitä ja henkilöhahmoja koskevissa käsityksissä. Vastaanottajien tulkintamalieja tarkastellaan suhteessa sosiaalisen kokemustaustan vaihteluun. Objektiivisten sosiaalisten asemien — luokan ja sukupuolen välisen vaihtelun lisäksi otetaan huomioon näiden asemien sisäinen vaihtelu, luokkaja genustietoisuudeksi jäsennetyt subjektiiviset sosiaaliset asemat. Birgitta Höijer keskittyy puolestaan mikrotasoon — vastaanottotapahtumaan sekä siihen liittyviin kognitiivisiin prosesseihin (vrt. Höijer 1988), joita hän tarkastelee muun muassa skeemateorian pohjalta.

\section{Katselun tuolla puolen}

Vastaanottotutkimuksen — kuten muunkin joukkoviestintätutkimuksen — olemassaolon oikeutena lienee se, että tavoitteena on viime kädessä selvittää vaikutuksia, sitä mitä merkitystä joukkoviestinnän olemassaololla taj — olemattomuudella on yksilöiden, yhteisöjen tai yhteiskunnan kannalta. Klaus Bruhn Jensen (1988) on esittänyt, että ainakin periaatteessa joukkoviestintätekstit saattavat toimia arkielämän sosiaalisessa vuorovaikutuksessa, poliittisessa, kulttuurisessa tai muussa sosiaalisessa toiminnassa käyttökelpoisina resursseina. Vaikutukset ovat tällöin sidoksissa siihen, miten relevantteja ja käyttökelpoisia tekstit ovat erilaisten sosiaalisten ryhmien ja instituutioiden poliittisen tai kulttuurisen toiminnan kannalta.

Alison Griffiths on pohtinut Pobol Y Cwm -sarjan vastaanottoa koskevia tuloksiaan samantapaisesta näkökulmasta. Hänen mukaansa Laakson kansan esiin tuomat monitahoiset ideologiset asemat tekevät sarjasta potentiaalisesti progressiivisen tekstin, jota voitaisiin käyttää hyväksi opetustarkoituksessa. Kulttuurista identiteettiä koskevalle pohdinnalle Laakson kansa tarjoaa oivan lähtökohdan. Lajityyppi on tuttu ja suosittu. Ohjelmassa kuvattu maailma on lähellä monien walesilaisten koettua elämää ja tarjoaa katsojille mahdollisuuden käyttää hyväksi omaa kulttuurista kompetenssiaan. Sen pohtiminen, miten kansalliseen ja kulttuuriseen identiteettiin liittyvät käsitykset ohjelmassa rakentuvat, ja mitä merkitystä niillä on kulttuuri-imperialismiin liittyvien kysy- 
mysten kannalta, saattaisi Griffithsin mukaan tarjota walesilaisille arvokkaita itsetiedostusta ja -tuntoa kohentavia kokemuksia.

Toisenlaisesta televisio-ohjelmien hyödyntämisestä on puhe Dorothy Hobsonin $(1989 ; 1990)$ tapaustutkimuksissa, joissa kuvataan kahden englantilaisen naisryhmän tapoja keskusteila televisio-ohjelmista työpaikalla. Toisen tapauskuvauksen aineistona on työryhmän yhdessä käymä keskustelu, toinen pohjautuu informanttihaastatteluun. Hobsonin mukaan tv-ohjelmien vastaanotto ulottuu pitkälle yli välittömän katselutilanteen ja myös myöhemmät arkikeskustelut ovat osa vastaanottoprosessia. Toisaalta televisio-ohjelmia koskevat keskustelut ovat osa työpaikkojen arkikulttuuria. Erilaisilla työpaikoilla televisio- ohjelmista juteliaan eri tavoin ja eri laajuudessa. Hobsonin tarkastelemille naisryhmille tv-ohjelmia koskeva keskustelu tarjosi mahdollisuuden luoda oma naiskulttuurin alue työpaikan sisälle. Omassa tapaustutkimuksessani (Montonen, painossa) olen kuvannut televisiokeskusteluja eräällä suomalaisella työpaikalla. Tapauskuvauksessa tarkastellaan kahta työryhmää, joista toinen hyödyntää televisio-ohjelmia sosiaalisena ja kulttuurisena resurssina oman työyhteisönsä ja työympäristönsä muodostamissa puitteissa.

Televisio-ohjelmien sosiaalista ja kultturista resurssikäyttöä koskevan tutkimuksen keskeisiä kysymyksiä ovat Jensenin mukaan se, millainen käsitys vastaanottajilla on erilaisten joukkoviestintätekstien kyvystä toimia resurssina, millaiset henkilöt erilaisiin kommunikaatiotilanteisiin osaliistuvat ja mitä he niissä tavoittelevat. Listaan tulisi vielä lisätä ainakin yksi olennainen kysymys: millaisia kompetensseja erilaiset tekstit ja tilanteet kommunikoijilta edellyttävät. Tätä kysymystä valottaa kaksi tuoretta tutkimusta.

Tamar Liebes ja Rivka Ribak (1991) ovat tapaustutkimuksessaan tarkastelleet sitä, miten yhden israelilaisperheen jäsenet keskustelevat televisiouutisista, ennen muuta arabien ja juutalaisten välisiin konflikteihin liittyvistä aineista. Keskusteluaineiston analyysissa on sovellettu Dallas-projektissa kehiteltyjä diskurssiluokituksia. Tutkimuksessa tarkastellaan sitä, millaisia mahdollisuuksia uutistekstit tarjoavat perheen sisällä tapahtuvaan poliittiseen sosialisaatioon. Tapaustutkimuksen perhe on jakautunut poliittisesti kahtia: perheen isä ja teini-ikäinen tytär ovat "haukkoja", äiti lukeutuu "kyyhkysiin".

Israelilaiset televisiouutiset nostavat yhden ideologisen aseman ylitse muiden uutistekstit suosivat jyrkkää, "haukkamaista" asennetta arabien kansannousua kohtaan. Vastaanoton kannalta tämä merkitsee sitä, että "haukat" voivat tulkita uutisia referentiaalisesti ("at face value") saadakseen tukea omille kannoilleen. "Kyyhkysiltä" keskusteluun osallistuminen ja omien asemien puolustaminen edellyttää sen sijaan huomattavan sofistikoitunutta uutistuotannon ja uutisten lajityypin tuntemusta. "Kyyhkysten" on kyettävä käsittelemään uutistodellisuutta välittyneenä todellisuutena.

Liebes ja Ribak kuvaavat poliittista sosialisaatiota prosessiksi, jossa erilaisten uutistulkintojen kautta ohjataan soveltamaan uutisiin erilaisia tulkintatapoja. "Haukkavanhemmalle" tehtävã on helppo. "Kyyhkysvanhemmalta" televisiouutisten hyväksikäyttö argumentoinnissa edellyttää sen sijaan melkoisia ponnistuksia. Avuksi on otettava muut tietolähteet - muut tekstit sekä omat ja muiden inmisten kokemukset todellisuudesta. 
Liebesin ja Ribakin tapauskuvaus on jännittävä, ehkä juuri siksi, että kyseessä on ääritapaus. Palestiinalaiskysymys on jakanut juutalaisväestön jyrkästi kahtia. Enin osa juutalaisperheistä on tutkijoiden mukaan kuitenkin poliittisilta kannoiltaan homogeenisia. Tapaustutkimuksen kahtia jakautunut perhe on löytynyt kyselytutkimuksen avulla. Lisäksi maassa on vain yksi julkinen televisiokanava, joka lähettää iltaa kohti vain yhdet varsinaiset uutiset. Kuten Liebes ja Ribak toteavat, kyseessä ovat ainutlaatuiset "laboratorio-olosuhteet". Saattaa kuitenkin olla, että juuri tällaiset olot paljastavat sellaisia pirteitä, joista "normaalimmassa" kontekstissa tehdyssä tutkimuksessa saataisiin vain viitteitä.

Kenneth Hacker kumppaneineen (Hacker ym. 1991) on käyttänyt hyväkseen Morleyn Nationwide-tutkimukseen pohjautuvan työn tarjoamia lähtökohtia mielenkiintoisessa kokeessa, jossa tutkijat opastivat amerikkalaisia yliopisto-opiskelijoita televisiouutisten dekonstruktioon. Dekonstruktio määriteltiin kyvyksi tunnistaa ja kritisoida uutisten ideologista sisältöä.

Kolmivaiheiseen opastus- ja tutkimusprosessiin osallistui 12 opiskelijaa. Kahdessa ensimmäisessä istunnossa opiskelijoille esitettiin valittuja paloja NBC:n uutisista. Opiskelijat vastasivat uutisia ja uutislähteitä koskevaan asennekyselyyn, kirjasivat paperille reaktioitaan ennalta laaditun kaavan mukaan ja lopuksi kommentoivat uutisia suullisesti. Suulliset kommentit videoitiin. Aikaa niiden esittämiseen oli varattu puolitoista minuuttia. Toiseen istuntoon sisältyi uutisdekonstruktion "pikakurssi". Tutkijat kertoivat, mitä mieltä he itse olivat uutisten ideologisesta sisällöstä sekä esittelivät uutistuotannon taloudellisia ja poliittisia taustoja. Kolmannessa istunnossa opiskelijoita haastateltiin henkilökohtaisesti. Opiskelijat katselivat ensin omista kommenteistaan tehdyt videonauhoitukset ja kommentoivat sitten omia reaktioitaan ja esittivät käsityksiään uutisdekontruktiosta.

Kertynyt materiaali analysoitin ja opiskelijoiden kommentit jaettiin luokkiin, jotka edustivat eri tasoisia vastustavia reaktioita uutisissa havaittuun ideologiseen sisältöön. Oppositionaalisten lausumien luokat on nimetty kritikiksi, resistanssiksi, kiistämiseksi ja dekonstruktioksi. Suurin osa oppositionaalisista lausumista oli pinnallista kritiikkiä (esim. "En pidä NBC:n uutisista."). Resistanssi — uutisten todenmukaisuuden kyseenalaistavat lausumat — oli suhteellisen harvinaista. Harvinaisinta oli uutisissa esitettyjen seikkojen kiistäminen asettamalla ne vastakkain jostain muusta lähteestä peräisin olevan tiedon kanssa ja dekonstruktio, huomion kiinnittäminen siihen tapaan, jolla uutiset suosivat jotakin ideologista lukutapaa. Lähes kaikki opiskelijat esittivät ainakin yhden dekonstruktiivisen lausuman, esimerkiksi kiinnittivät huomiota siihen, mitä uutistekstissä jätettiin käsittelemättä. Tämän tutkijat arvelevat heijastavan opastuksen vaikutusta. Yksi opiskelijoista oli tässä suhteessa kompetentti jo ennen opastusta: lähes kolmannes kaikista dekonstruktivisista lausumista sisältyi tämän henkilön kommentteihin.

Hackerin ym. mukaan vastaanottajat eivät kykene käsittelemään kaikkia uutisissa tunnistamiaan ideologisia piirteitä. Vastaanottajat saattavat samanaikaisesti sekä kyseenalaistaa televisiouutisten todellisuuskuvan että osoittaa ymmärrystä uutistuotantoa sääteleviä taloudellisia vaatimuksia kohtaan.

Opastusintervention ansiosta useimmat vastaanottajat kykenivät havaitsemaạn 
uutisteksteissä ideologisia painotuksia ja vääristymiä. Niiden dekonstruktiivinen käsittely oli sen sijaan vaikeaa, koska vastaanottajilla ei ollut käytettävissään riittävästi vaihtoehtoisia tietoja ja tietolähteitä. Johtopäätöksenä tutkijat esittävät, että uutisdekonstruktiota voidaan opettaa sellaisille vastaanottajille, jotka haluavat tietoja maailman tapahtumista "ideologiavapaina". Kaikkien he eivät usko tällaista opetusta kuitenkaan haluavan.

\section{Vastaanottotutkimuksen yhteiskunnallinen relevanssi}

Jensen ja Rosengren (1989) ovat pohtineet sitä, onko vastaanottotutkimuksella jotakin erityistä yhteiskunnallista relevanssia. Vastaus on sikäli kielteinen, että he eivät näe vastaanottotutkimuksen ja sen sovellutusten tarjoavan mitään uutta suhteessa siihen mitä kulttuuritutkimus, kirjallisuustutkimus ja sosiaalitieteellinen yleisötutkimus tarjoavat. Kulttuuritutkimuksella, kirjallisuustutkimukselia ja vastaanottotutkimuksella on heidän mukaansa samanlaista relevanssia koulutuksen kannalta. Nämä tutkimusalat voivat uusien opetusmenetelmien ja -sisältöjen kehittämisen kautta tarjota yleisölle parempia eväitä joukkoviestinnän hyväksikäyttöön ja poliittiseen toimintaan. Ne voisivat myös osoittaa poliittisille päätöksentekijöille, miten viestinnän ja kulttuurin institutionaalinen kehikko tulisi organisoida uudelleen siten, että se palvelisi paremmin käyttäjiensä intressejä. Yhteistä vastaanottotutkimukselle ja sosiaalitieteelliselle yleisötutkimukselle on Jensenin ja Rosengrenin mukaan se, että kumpikin tuottaa yleisön tulkintatavoista ja elämäntyyleistä sellaista tietoa, joka voi palvella joukkoviestintäinstituutioiden ja mainostajien tarpeita.

Televisiotuotannon pirissä kiinnostus kvalitatiiviseen empiiriseen yleisötutkimukseen ei ole uutta. Kiinnostus näyttää kuitenkin olevan kohoamassa uudelie tasolle. Konkreettisia esimerkkejä ovat Yleisradion piirissä hiljan valmistuneet vastaanottotutkimukset (Alasuutari \& al. 1991; Kytömäki 1991) ja saman laitoksen helmikuulle suunnittelema kvalitatiivisen yleisötutkimuksen kansainvälinen seminaari. Viestintäkasvatuksella ja vastaanottotutkimukseila on sen sijaan toistaiseksi ollut varsin vähän yhtymäkohtia. Samoin on laita Jensenin ja Rosengrenin mainitseman viestinnän ja kultuurin institutionaalisen kehikon uudelleenorganisoinnin suhteen. Tätä aluetta on sivunnut lähinnä vastaanottotutkimusten pohjalta virinnyt keskustelu siitä, miten esimerkiksi tv-ohjelmien tuotantoon, levitykseen ja kritiikkiin sovellettavia laatukriteerejä voitaisiin muokata uuteen uskoon (Schrøder 1989; Gripsrud 1989).

Kypsyyden vaihetta televisio-ohjelmien vastaanottotutkimus ei näytä saavuttaneen: tutkijat ovat tulossa useiden erilaisten tutkimusperinteiden piiristä ja matkalla moneen suuntaan. "Kypsyyden" voi tässä yhteydessä ymmärtää jähmeäksi aloilleen asettumiseksi, kelvollisiksi havaittuja kaavoja noudattavien tutkimusten rutiinimaiseksi tuotannoksi. Jähmeyden vastakohta on joustavuus, paikoilleen asettumisen kehittely ja kokeilu — silläkin uhalla, että osa lupaavista suunnista osoittautuisi umpiperiksi. 


\section{Kirjallisuus}

ALASUUTARI, Pertti \& KYTÖMÄKI, Juha. Johdanto. Teoksessa: KYTŌMÄKI, Juha (toim.). Nykyajan sadut. Joukkoviestinnän kertomukset ja vastaanotto. Gaudeamus \& Yleisradio, Helsinki 1991.

ALASUUTARI, Pertti, ARMSTRONG, Karen \& KYTÖMÄKI, Juha. Reality and Fiction in Finnish Tr Viewing. Research Report 3/1991. Yleisradio, Helsinki 1991.

BILTEREYST, Daniel. Decoding and impact of US fiction in a small European country. IV International Television Studies Conference, London 1991.

DAHLGREN, Peter. Mitä se merkitsee? Tiedotustutkimus 10(1987):3, s. 3-15.

FREY-VOR, Gerlinde. Lindenstrasse: The first German soap opera in comparison with its British Models. IV International Television Studies Conference, London 1991.

GRIFFITHS, Alison Margaret. Pobol Y Cwm: The Construction of National and Cultural Identity in a Welsh Language Soap Opera. IV International Television Studies Conference, London 1991.

GRIPSRUD, Jostein. Genres and qualities. Preliminary notes on hierarchies of texts and tastes. IX Nordic Conference of Mass Communication Research, 1989.

HACKER, Kenneth L., COSTE, Tara G., KAMM, Daniel F. \& BYBEE, Carl R. Oppositional readings of network television news: viewer deconstruction. Discourse \& Society 2(1991):2, s. 198-202.

HJORT, Anne. Kvinderne og Dallas. Teoksessa: PITTELKOW, R. (toim.). Analyser af tv. Mediet og dets modtagere. Medusa, København 1985.

HOBSON, Dorothy. Soap operas at work. Teoksessa: SEITER, E. \& al. (toim.). Remote Control. Television, Audiences, and Cultural Power. Routledge, London \& New York 1989.

HOBSON, Dorothy. Women Audiences at the Workplace. Teoksessa: BROWN, M.E. (toim.). Television and Women's Culture. The Politics of the Popular. Sage, London etc. 1990.

HÖlJER, Birgitta. Studying Viewer Reception of Television Programs by In-Depth Interviews: Theoretical and Methodological Considerations. Conference of International Association for Mass Communication Research, Barcelona 1988.

HÖIJER, Birgitta, NOWAK, Kjell \& ROSS, Sven. Reception av TV som kognitiv och kulturell process (REKK). X Nordiska konferensen för masskommunikationsforskning, Reykjavik, 1991.

JENSEN, Klaus Bruhn. Surplus Meaning: Outline of a Social Theory of Media Reception. SPIEL, 7(1988):2, s. 293-311.

JENSEN, Klaus Bruhn \& ROSENGREN, Karl Erik. Five traditions in search of the audience: Towards a typology of research on the reception, uses, and effects of mass media content. Forsknings- rapporter i kommunikationssociologi 19. Department of Sociology, University of Lund 1989.

KYTÖMÄKI, Juha (toim.). Nykyajan sadut. Joukkoviestinnän kertomukset ja vastaanotto. Gaudeamus \& Yleisradio, Helsinki 1991.

LIEBES, Tamar \& KATZ, Elihu. The Export of Meaning. Cross-cultural readings of Dallas. Oxford University Press, New York \& Oxford 1990.

LJEBES, Tamar \& RIBAK, Rivka. A mother's battle against tv news: a case study of political socialization. Discourse \& Society 2(1991):2, s. 203-222.

MALWADE-RANGARAJAN, Amita. Television and Social Identities: Audience Interpretations of "Hum Log", An Indian Soap Opera. IV International Television Studies Conference, London 1991.

MONTONEN, Marjatta. Alkoholi televisiodraamassa - vertaileva vastaanottolutkimus. 
Viestinnän lisensiaatintutkimus, Helsingin yliopisto 1991.

MONTONEN, Marjatta. Televisio työpaikkakeskusteluissa. Ilmestyy Kulttuuritutkimus-lehdessä.

MONTONEN, Marjatta. TV-ohjelmien vastaanoton analyysi. Teoksessa: MÄKELÄ, K. (toim.). Kvalitatiivisen aineiston analyysi ja tulkinta. Gaudeamus, Helsinki 1990.

MORLEY, David. The "Nationwide" Audience: Structure and Decoding. British Film Institute, London 1980.

ROSCOE, Jane. Exploring the Ideology in Soap: A Discourse Analysis of the Text and Viewers Interpretations of Two British Soap Operas. IV International Television Studies Conference, London 1991.

SCHRøDER, Kim. The playful audience. The continuity of the popular cultural tradition in America. Teoksessa: SKOVMAND, M. (toim.). Media Fictions. The Dolphin no. 17. Aarhus University Press, Aarhus 1989.

\section{$\overline{\text { PERTTI SUHONEN }}$}

\section{Onko vastaanottotutkimusta olemassa?}

Onko sitä olemassa jonakin sellaisena tutkimuksen alueena, joka voidaan määritellä ja ominaispiirteidensä perusteella rajata erilleen muusta viestintätutkimuksen kentästä?

Marjatta Montosen artikkeli on mainio katsaus tuoreeseen televisio-ohjelmien ja niiden yleisön välisiä suhteita koskevaan tutkimukseen. Kymmenkunta hänen esittelemäänsä tutkimusta 80-luvun lopulta ja 90-luvun alusta ovat tiedonintresseiltään, metodeiltaan ja teoreettisilta lähtökohdiltaan varsin kirjava joukko. Tutkimusmenetelmien kirjo kiihottaa mielikuvitusta, jota ei liian tuhlailevasti ole käytetty suomalaisessa viestintätutkimuksessa.

Vaikka Montonen käsitteleekin kirjoituksessaan tv-ohjelmien vastaanottotutkimuksia, ne eivät hänen selostuksestaan päätellen kuitenkaan painota television erityisyyttä vastaanoton kannalta. Useimmissa esimerkeissä tutkimuksen lähtökohta ja tutkimusasetelma sopisivat yhtä hyvin muiden kulttuurituotteiden vastaanoton tutkimiseen.

Mutta mikä esiteltyjä tutkimuksia yhdistää vastaanottotutkimukseksi ja erottaa muusta yleisötutkimuksesta? Montosen mainitsema Klaus Bruhn Jensenin ja Karl Erik Rosengrenin vastaanottotutkimuksen luonnehdinta sisältää nähdäkseni kolme erottelukykyistä ulottuvuutta: tutkimusalue pyrkii yhdistämään sosiaalitieteellisisä ja humanistisia näkökulmia, kohteena on sekä joukkoviestinnän sisältö että yleisö ja tutkimus on kvalitatiivista.

Kvalitatiivisuus vastaanottotutkimuksen erityisenä piirteenä ei saa tukea Montosen esittelemien tutkimusten perusteella. Niistä lähes puolet perustui tutkimusasetelmaltaan määrällisten erittelyjen tekoon. Kun tutkimustehtävänä on selvittää missä 